\title{
Antifungal susceptibility evaluation of Candida albicans isolated from buccal lesions of hiv-positive and HIV-negative patients
}

\author{
Irany Mesquita COELHO ${ }^{1}$ \\ André Luis Ribeiro CLAUDINO ${ }^{2}$ \\ Juliana Moscardini CHAVASCO ${ }^{3}$ \\ Esther Goldenberg BIRMAN ${ }^{4}$ \\ Walderez GAMBALE ${ }^{5}$ \\ Natanael Atilas ALEVA ${ }^{6}$ \\ Amanda Latercia Tranches DIAS ${ }^{7}$ \\ Claudete Rodrigues PAULA ${ }^{8}$ \\ Jorge Kleber CHAVASCO ${ }^{9}$
}

\footnotetext{
${ }^{1}$ Mestre em Microbiologia, UNIFAL-MG- iranymcm@yahoo.com.br,

${ }^{2}$ Mestre em Ciências Farmacêuticas,UNIFAL-MG, andrebiofar@yahoo.com.br

${ }^{3}$ Farmacêutica, Professora Titular da UNIVAS e Supervisora do Controle de Qualidade da União Química Farmacêutica

Nacional. julianamoscardini@bol.com.br

${ }^{4}$ Livre-docente, Faculdade de Odontologia -USP (Universidade de São Paulo), egbirman@usp.br

${ }^{5}$ Professor Assistente-doutor, Instituto de Ciências Biomédicas (ICB)/USP, vgambale@usp.br

${ }^{6}$ Cirurgião Dentista e Professor de Graduação e Pós Graduação do INAPÓS ( Pouso Alegre-MG)

natanaelaleva@terra.com.br

${ }^{7}$ Professor adjunto, UNIFAL-MG, amanda.dias@unifal-mg.edu.br

${ }^{8}$ Professor Assistente-doutor, ICB/USP, crpmicol@uol.com.br

${ }^{9}$ Professor associado, Universidade Federal de Alfenas (UNIFAL-MG) (Orientador), jkchavasco@uol.com.br

*Autor correspondente:

Prof. Dr. Jorge Kleber Chavasco

Universidade Federal de Alfenas (UNIFAL-MG)

Rua Gabriel Monteiro da Silva 700

37130-000, Alfenas-MG

Telefone: 35-3299-1305

Email: jkchavasco@uol.com.br
}

\begin{abstract}
The antifungal minimal inhibitory concentrations (MIC) were determined to 35 samples of Candida albicans; 14 of them were isolated from HIV-positive patients, and 21 from HIV-negative patients with oral erythematous candidosis. The aim of this study was to evaluate the performance of agar dilution method in the determination of susceptibility of Candida albicans isolated from buccal lesions of HIV-positive and negative patients to some antifungals and compare the results with the plasmatic concentration reached by each one of these drugs. The samples were evaluated in vitro by the agar dilution method and showed higher MIC values to ketoconazole, fluconazole, itraconazole and amphotericin B than the concentrations achieved by these antifungals in plasma. $88.9 \%$ of the samples presented in vitro resistance to ketoconazole and the plasmatic levels of this antifungal varied from 1 to $8 \mu \mathrm{g} / \mathrm{mL}$. Regarding fluconazole and itraconazole, most samples presented MIC larger than $128 \mu \mathrm{g} / \mathrm{mL}$ and plasmatic concentration varying from 0.4 to $8 \mu \mathrm{g} / \mathrm{mL}$. Only $11.9 \%$ of the samples were susceptible in vitro to fluconazole and $2.7 \%$ of them to itraconazol. The usage concentrations prescribed for the topical antifungals nystatin, fenticonazole and miconazole are markedly higher than the values of MIC obtained. Related to nystatin, it was verified that its MIC values were between 1 and $4 \mu \mathrm{g} / \mathrm{mL}$. The plasmatic levels to this drug are extremely low. Fenticonazole presented a MIC value larger than $128 \mu \mathrm{g} / \mathrm{mL}$. Relating to miconazole, the plasmatic levels vary from 1 to $8 \mu \mathrm{g} / \mathrm{mL}$ and $11.9 \%$ of the samples presented in vitro susceptibility to this drug. No significant differences $(p<0.05)$ were found in the susceptibility profiles of the samples obtained from HIVpositive and HIV-negative patients.
\end{abstract}

Keywords: Candida albicans. Antifungal. MIC. Drug plasmatic level. HIV. Agar diffusion test 


\section{INTRODUCTION}

Candida species are ubiquitous human fungal pathogens that are capable of initiating a variety of recurring superficial diseases especially in the oral and vaginal mucosae (MACPHAIL et al, 1993). The administration of broad-spectrum antibiotics, the extensive use of steroids, immunosuppressive agents in cases of organ transplant and the use of antineoplastic contributing to the increasing morbidity associated with Candida. In the last years, mucosal Candida infections have received a great attention due to the advance of HIV infection. For instance, it is known that up to 90\% of HIV-infected individuals suffer from oropharyngeal candidiasis

(SAMARANAYAKE，MACFARLANE，1990; YUTHIKA et al, 2001).

Oropharyngeal candidiasis, usually diagnosed in more than $75 \%$ of the patients with AIDS, during elapsing of their illness, besides relapsing at high frequency, leads to a discomfort during food mastication and may result in great weakness for the organism and alteration of the immunological state and so, an effective antifungical treatment is made necessary and in a fast way (COLOMBO, 1994; DUPONT et al, 1994; IWATA, 1992; KERRIDGE; NICHOLAS, 1986). The frequent use of antifungal therapy in patients with AIDS, due to the constant recurrence of buccal or esophageal candidiasis, is a factor that probably influences on the occurrence of resistance to different drugs (TERREL; HUGHES, 1992).

A number of antifungal agents are available for the management of candidal infections. The major agents that are currently used for oropharyngeal candidiasis are the polyenes: amphotericin B and nystatin, the imidazoles: clotrimazole, econazole, ketoconazole, and miconazole, the triazoles: fluconazole, itraconazole, voriconazole; the echinocandins: caspofungina, anidulafungina, micafungina (MCGINNIS, RINALDI, 1996; JOHNSON and KAUFFMAN, 2003; BORMANN and MORRISON, 2009; MARIO et al., 2012).

The introduction of the imidazole and azole groups of antifungals during the last two decades has modified the management of fungal infections. One of the first effective medicines on the candidiasis treatment was the nystatin. This drug, however, is ideal for topical treatment of oral infections since it is not absorbed from the gastrointestinal tract and the adverse effects are minimal. It presents toxicity only when used by intravenous access. In function of that, new researches continue to be done, proposing the amphotericin B use, that is highly effective but is also endowed of treatment-limiting adverse effects such as nephrotoxicity (MEDOFF; KOBAYASHI, 1980; MEYER, 1994 ;WALSH et al, 1994). 
The great number of antifungal drugs, the resistance report verified in Candida isolates, mainly in immunocompromised patients, and the need of a fast and effective treatment suscite a great interest in studies capable of standardizing tests of "in vitro"susceptibility for the choice of the appropriate therapy (ALVES, CURY, 1992; COLOMBO, 1994; GALGIANI et al, 1992; KORTING et al, 1988; MERZ,1986; SHADOMY; PFALLER, 1991).

Nowadays, a great part of efforts to develop a routine method for testing susceptibility of yeasts to antifungal agents has employed different species of Candida and this development is necessary in order to supply valuable information concerning the research of new substances, resistance to antifungals of frequent use, therapeutic control of infections and characterization of yeast samples (KORTING et al, 1988; MERZ, 1986; SHADOMY; PFALLER, 1991).

Besides the lack of usage of a single method for antimicrobial evaluation, their results can be compared (GALGIANI et al., 1992; LACAZ et al., 1991). By this way, the development of standardized antifungal susceptibility testing methods has been the subject of numerous studies during the last decades ( REX et al., 2001; CLSI, 2008 ) and they have been, in their majority, adaptations of those ones proposed to bacteria. The available techniques are based on broth dilution and on agar-dilution test and agar-diffusion test (ALVES, CURY, 1992; CURY, MICHE, 1989; CURY et al., 1989; ESPINELL-INGROFF et al., 1992; MERZ, 1986; PFALLER et al., 1992). In the agar-diffusion test, the disks contain only one concentration of the drug, classifying the microorganism in susceptible, intermediate or resistant to that drug, usually in agreement with the plasmatic concentration reached by the drug (REX et al, 1993).

The aim of this study was to evaluate the performance of agar dilution method in the determination of susceptibility of Candida albicans isolated from buccal lesions of HIVpositive and negative patients to some antifungals and compare the results with the plasmatic concentration reached by each one of these drugs.

\section{MATERIALS AND METHODS}

Samples. Thirty five samples of C. albicans, coming from HIV positive (14) and HIV negative (21) patients with erythematous oral candidiasis. The collection and evaluation were approved by the Research Ethics Committee of the Universidade Vale do Rio Verde (protocol 196/1996). C. albicans ATCC 10231 was employed as standard sample. These samples are maintained at the fungus collection of mycology laboratory in the ICB/USP, São Paulo. 
Antifungal susceptibility testing. We employed the proposed methodology of agar dilution according to ALVES and CURY, 1992. All drugs were obtained as reagent grade powders and were kindly supplied by the mentioned laboratories being nystatin and amphotericin B from Bristol-Myers Squibb (São Paulo, Brazil); fenticonazole from Asta Doctor (São Paulo, Brazil); fluconazole from Pfizer (São Paulo, Brazil), ketoconazole, itraconazole and miconazole from Jansen-Pharmaceutical Cilag (São Paulo, Brazil).

Antifungal stock solution. $25.6 \mathrm{mg}$ of each antifungal were weighted and dissolved in 1 $\mathrm{mL}$ of dimethyl sulphoxide and itraconazol was solely dissolved in polyethyleneglycol. After the preparation in a glass sterile tube, the solution was allowed to rest by 10 minutes for self- sterilization.

\section{Procedures of drug dilutions and culture} media preparation. A series of 10 tubes was prepared, from which the first one contained 19 $\mathrm{mL}$ of the broth Yeast Nitrogen Base Fosfate (YNBP), and the others, each one contained 7 $\mathrm{mL}$ of the same broth. To the first tube, $1 \mathrm{~mL}$ of the antifungal stock solution was added followed by homogenization. Starting from this tube, serial dilutions were accomplished in duplicate, reaching up the tube number 10 . From each tube of the series, $2 \mathrm{~mL}$ were transferred to other 10 tubes containing each one $18 \mathrm{~mL}$ of YNBP agar maintained at $45^{\circ} \mathrm{C}$. After homogenization, the medium with the incorporated drug was flowed in sterile Petri plates. After solidification, these were conserved in refrigerator at $4^{\circ} \mathrm{C}$ for one week. The final concentrations of the drugs ranged between $0.25 \mu \mathrm{g} / \mathrm{mL}$ to $128 \mu \mathrm{g} / \mathrm{mL}$.

Inoculum preparation. Starting from the $48 \mathrm{~h}$ cultivations of the C. albicans samples at $25^{\circ} \mathrm{C}$, on Sabouraud-dextrose agar, suspensions in 5 $\mathrm{mL}$ of phosphate buffer were made with tween 80. The inoculum was standardized to $10^{6} \mathrm{UFC}$ / mL, approximately (GALGIANI et al, 1992; PFALLER et al, 1988; SHADOMY; PFALLER, 1991).

\section{Determination of the minimum inhibitory} concentration. The standardized suspensions of C. albicans were inoculated in a volume of 10 $\mu \mathrm{L}$ on the welled agar plates containing the antifungal drug. A total of 20 samples were inoculated per plate. After the natural drying of the inoculum, the plates were incubated at $37^{\circ} \mathrm{C}$ for $24 \mathrm{~h}$. The reading was accomplished $48 \mathrm{~h}$ later by the observation of the presence or absence of yeast growth around the well. The minimum inhibitory concentration was considered the smallest concentration of the drug that hinded the growth of the yeast. 
Quality Control. All susceptibility tests were repeated five times. The potency and viability of stock solutions were controlled. Periodic evaluations were realized with standard $C$. albicans sample ATCC 10231, whose antifungal susceptibility profile has been previously established.

Statistical Analysis. The software GraphPad Prism (version 5.0, 2007) was used to compare two independent samples to evaluate the different groups (susceptible strains vs. resistant strains in HIV positive or HIV negative patients).

\section{RESULTS AND DISCUSSION}

The MICs for 35 samples of $C$. albicans were ascertained, being 14 of them isolated from HIV positive and 21 from HIV negative patients and 1 standard strain of C. albicans ATCC 10231. The samples 03 to 31 correspond to HIV negative patients and the samples 32 to 52 to HIV-positive patients (Table 01).

In the case of amphotericin B, the MIC values were between 2 and $4 \mu \mathrm{g} / \mathrm{mL}$. The plasmatic levels of this antifungal varied from 1 to $2 \mu \mathrm{g} / \mathrm{mL}$. By this way, it was verified that a large percentage (61\%) of these samples presented MIC values superior to $2 \mu \mathrm{g} / \mathrm{mL}$ and showed themselves an "in vitro" resistance to the drug. SOUZA et al (1990) and MAFFEI (1996) found $100 \%$ of the samples susceptible to this drug (Table 01) but HSUEH et al (2005) found 11\% (23 of 2007 isolates) of resistance for $C$. albicans isolates. The amphotericin B MIC and plasmatic concentrations results among samples from HIV positive patients didn't differ $(p<0.05)$ from HIV negative ones.

Regarding Ketoconazole, it was verified the MIC values between 32 and $64 \mu \mathrm{g} / \mathrm{mL}$ for most of the samples. The plasmatic levels of this antifungal varied from 1 to $8 \mu \mathrm{g} / \mathrm{mL}$, showing, therefore, that most of the samples $(88,9 \%)$ present "in vitro" resistance to it. There weren't seen statistical differences $(p<0.05)$ among samples from HIV positive and negative patients. Similar results were obtained by MAFFEI (1996), who applied the same technique that us (Table 01).

Fenticonazole presented a MIC value larger than $128 \mu \mathrm{g} / \mathrm{mL}$ to samples from HIV positive and negative patients without statistical differences $\quad(p<0.05)$ among them. This antifungal is relatively new and its use is restricted to topical applications, being the vaginal cream with a concentration of $2.0 \%$ and the vaginal ovule with $600 \mathrm{mg}$ of the drug. These concentrations is much larger than the values of MICs we found (Table 01).

Regarding fluconazole and itraconazole, the results obtained were similar to those of fenticonazole, that is, most samples presented MIC larger than $128 \mu \mathrm{g} / \mathrm{mL}$ (Table 01), and plasmatic concentration varying from 0.4 to 8 
$\mu \mathrm{g} / \mathrm{mL}$. By this way, we verified that only $11.9 \%$ of the samples were susceptible "in vitro" to fluconazole and $2.7 \%$ of them to itraconazol without statistical differences $(p<0.05)$ among samples from HIV positive and negative patients. Similar results were achieved by MAFFEI (1996), who observed a susceptibility to fluconazole for only $4.2 \%$ of the tested samples but these results shown discrepancies in relation to the results achieved by MENON et al. (2001) in that out of 16 strains of C. albicans isolated from oral lesions, one was resistant to fluconazole where as all were susceptible to itraconazole and in their research the "in vitro" MIC values correlated well with "in vivo" responses in patients. MOHANTY et al. (2007) didn't find complete resistance in any of the Candida species evaluated against fluconazole by broth microdilution method.

In the case of miconazole, taking into account that the plasmatic levels vary from 1 to $8 \mu \mathrm{g} / \mathrm{mL}$, it was verified that only $11.9 \%$ of the samples presented "in vitro" susceptibility to the drug. The MIC ranged from 0.25 to 64 $\mu \mathrm{g} / \mathrm{mL}$. No statistical differences $(p<0.05)$ were seen among samples from HIV positive and negative patients. MAFFEI (1996) encountered values different from ours, that is, approximately, $60 \%$ of samples were susceptible through "in vitro" evaluations. Miconazole is an antifungal of topical use, and the usage concentration is much higher than its plasmatic concentration (Table 01).

Related to nystatin, it was verified that its MIC values were between 1 and $4 \mu \mathrm{g} / \mathrm{mL}$. The plasmatic levels to this drug are extremely low by considering that nystatin is not absorbed orally. No statistical differences $(p<0.05)$ were seen among samples from HIV positive and negative patients. The medicines based on nystatin are used broadly for oral candidiasis, and its concentration in those products is approximately 5,000 IU/mg, what corresponds to $1.02 \mathrm{mg}$ of the drug (DEF, 2002). This concentration is higher than the MIC values found in our studies (Table 01).

Concerning the samples collected from HIV-positive patients, one could also observe that, when they were compared to the samples collected from HIV-negative patients, there were no significant differences $(p<0.05)$ in the resistance profile to the evaluated antifungals.

\section{CONCLUSIONS}

1 - Most antifungals exhibited MIC values higher than the respective plasmatic concentrations, what suggests that the samples present an "in vitro" resistance.

2 - Despite showing higher MIC values than the values of their plasmatic concentrations, fenticonazole, miconazole and nystatin were 
shown to have topical use concentrations higher than the MIC values.

3 - No statistical differences were found in the from either HIV positive or HIV negative patients.

Table 01 - Determination of the minimum inhibitory concentration of antifungals on samples of $C$. albicans isolated from HIV-positive patients and HIV-negative patients with erythematous oral candidosis .

\begin{tabular}{|c|c|c|c|c|c|c|c|c|}
\hline \multirow{2}{*}{$\begin{array}{c}\text { Number of the } \\
\text { sample }\end{array}$} & \multirow{2}{*}{$\begin{array}{l}\text { Reference } \\
\text { number at } \\
\text { ICB/USP }\end{array}$} & \multicolumn{7}{|c|}{ Minimum inhibitory concentration of the antifungals in $\mu \mathrm{g} / \mathrm{mL}$} \\
\hline & & 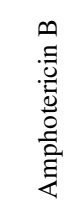 & 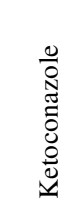 & 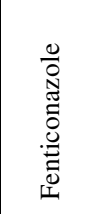 & 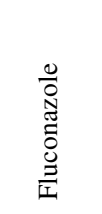 & 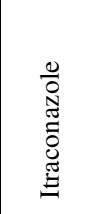 & 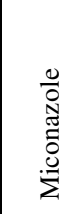 & $\begin{array}{l}\text { 丞 } \\
\text { 之े } \\
\text { 乙 }\end{array}$ \\
\hline Standard & $12 \mathrm{~A}$ & 1.0 & 4.0 & $>128.0$ & 0,25 & 0,25 & 16.0 & 1.0 \\
\hline 3 & $28 \mathrm{P}$ & 2.0 & 32.0 & $>128.0$ & 4.0 & $>128.0$ & 32.0 & 4.0 \\
\hline 4 & $13 \mathrm{P}$ & 4.0 & 16.0 & $>128.0$ & 128.0 & $>128.0$ & 16.0 & 2.0 \\
\hline 6 & $20 \mathrm{P}$ & 4.0 & 32.0 & $>128.0$ & 32.0 & $>128.0$ & 32.0 & 2.0 \\
\hline 7 & $8 \mathrm{P}$ & 0.25 & 4.0 & $>128.0$ & $>128.0$ & $>128.0$ & 0.25 & 4.0 \\
\hline 11 & $18 \mathrm{P}$ & 2.0 & 32.0 & $>128.0$ & $>128.0$ & $>128.0$ & 32.0 & 4.0 \\
\hline 12 & $4 \mathrm{P}$ & 4.0 & 4.0 & $>128.0$ & $>128.0$ & $>128.0$ & 32.0 & 4.0 \\
\hline 13 & $35 \mathrm{P}$ & 2.0 & 32.0 & $>128.0$ & $>128,0$ & $>128.0$ & 64.0 & 4.0 \\
\hline 14 & $2 \mathrm{P}$ & 4.0 & 32.0 & $>128.0$ & $>128.0$ & $>128.0$ & 32.0 & 4.0 \\
\hline 15 & $23 \mathrm{P}$ & 4.0 & 32.0 & $>128.0$ & $>128.0$ & $>128.0$ & 32.0 & 4.0 \\
\hline 16 & $22 \mathrm{P}$ & 2.0 & 32.0 & $>128.0$ & $>128.0$ & $>128.0$ & 8.0 & 2.0 \\
\hline 20 & $6 \mathrm{P}$ & 2.0 & 32.0 & $>128.0$ & $>128.0$ & $>128.0$ & 16.0 & 4.0 \\
\hline 21 & $17 \mathrm{P}$ & 4.0 & 32.0 & $>128.0$ & $>128.0$ & $>128.0$ & 32.0 & 4.0 \\
\hline 22 & $37 \mathrm{P}$ & 4.0 & 32.0 & $>128.0$ & $>128.0$ & $>128.0$ & 32.0 & 4.0 \\
\hline 23 & $27 \mathrm{P}$ & 4.0 & 32.0 & $>128.0$ & $>128.0$ & $>128.0$ & 32.0 & 4.0 \\
\hline 24 & $34 \mathrm{P}$ & 2.0 & 64.0 & $>128.0$ & $>128.0$ & $>128.0$ & 64.0 & 4.0 \\
\hline 25 & $24 \mathrm{P}$ & 4.0 & 32.0 & $>128.0$ & $>128.0$ & $>128.0$ & 32.0 & 4.0 \\
\hline
\end{tabular}


Table 01 (Cont.) - Determination of the minimum inhibitory concentration of antifungals on samples of C. Albicans isolated from HIV-positive patients and HIV-negative patients with erythematous oral candidosis

\begin{tabular}{|c|c|c|c|c|c|c|c|c|}
\hline \multirow{2}{*}{$\begin{array}{l}\text { Number of the } \\
\text { sample }\end{array}$} & \multirow{2}{*}{$\begin{array}{l}\text { Reference } \\
\text { number at } \\
\text { ICB/USP }\end{array}$} & \multicolumn{7}{|c|}{ Minimum inhibitory concentration of the antifungals in $\mu \mathrm{g} / \mathrm{mL}$} \\
\hline & & 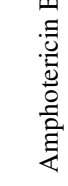 & 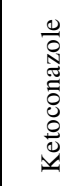 & 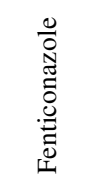 & 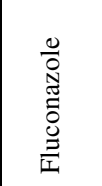 & 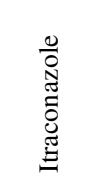 & 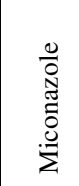 & 丞 \\
\hline 26 & $39 \mathrm{P}$ & 4.0 & 32.0 & $>128.0$ & $>128.0$ & $>128.0$ & 16.0 & 4.0 \\
\hline 28 & $32 \mathrm{P}$ & 4.0 & 32.0 & $>128.0$ & $>128.0$ & $>128.0$ & 4.0 & 4.0 \\
\hline 29 & $44 \mathrm{P}$ & 4.0 & 32.0 & $>128.0$ & $>128.0$ & $>128.0$ & 32.0 & 4.0 \\
\hline 30 & $11 \mathrm{P}$ & 2.0 & 32.0 & $>128.0$ & $>128.0$ & $>128.0$ & 64.0 & 4.0 \\
\hline 31 & $40 \mathrm{P}$ & 2.0 & 32.0 & $>128.0$ & $>128.0$ & $>128.0$ & 32.0 & 4.0 \\
\hline 32 & $7 \mathrm{H}$ & 4.0 & 32.0 & $>128.0$ & $>128.0$ & $>128.0$ & 32.0 & 4.0 \\
\hline 33 & $6 \mathrm{H}$ & 4.0 & 32.0 & $>128.0$ & $>128.0$ & $>128.0$ & 32.0 & 4.0 \\
\hline 34 & $23 \mathrm{PH}$ & 4.0 & 64.0 & $>128.0$ & $>128.0$ & $>128.0$ & 32.0 & 4.0 \\
\hline 35 & $17 \mathrm{H}$ & 4.0 & 64.0 & $>128.0$ & $>128.0$ & $>128.0$ & 32.0 & 4.0 \\
\hline 36 & $23 \mathrm{LH}$ & 2.0 & 64.0 & $>128.0$ & $>128.0$ & $>128.0$ & 32.0 & 4.0 \\
\hline 37 & $26 \mathrm{H}$ & 2.0 & 32.0 & $>128.0$ & $>128.0$ & $>128.0$ & 16.0 & 4.0 \\
\hline 43 & $1 \mathrm{H}$ & 4.0 & 32.0 & $>128.0$ & $>128.0$ & $>128.0$ & 32.0 & 4.0 \\
\hline 44 & $14 \mathrm{H}$ & 4.0 & 32.0 & $>128.0$ & $>128.0$ & $>128.0$ & 16.0 & 4.0 \\
\hline 46 & $9 \mathrm{H}$ & 4.0 & 8.0 & $>128.0$ & $>128.0$ & $>128.0$ & 4.0 & 2.0 \\
\hline 47 & $13 \mathrm{H}$ & 4.0 & 32.0 & $>128.0$ & $>128.0$ & $>128.0$ & 32.0 & 4.0 \\
\hline 48 & $3 \mathrm{H}$ & 2.0 & 32.0 & $>128.0$ & $>128.0$ & $>128.0$ & 32.0 & 4.0 \\
\hline 49 & $21 \mathrm{PH}$ & 2.0 & 64.0 & $>128.0$ & $>128.0$ & $>128.0$ & 64.0 & 4.0 \\
\hline 51 & $25 \mathrm{H}$ & 4.0 & 64.0 & $>128.0$ & $>128.0$ & $>128.0$ & 32.0 & 4.0 \\
\hline 52 & $11 \mathrm{H}$ & 4.0 & 32.0 & $>128.0$ & 2.0 & $>128.0$ & 32.0 & 4.0 \\
\hline
\end{tabular}




\section{REFERENCES}

1.ALVES, S.H; CURY, A. E. Estudo comparativo entre as técnicas de diluição em caldo e diluição em agar nos antibiogramas pra Cândida. Revista do Instituto de Medicina Tropical de São Paulo, 34: 259-262, 1992.

2.BORMANN, A.M.; MORRISON, V.A. Review of the pharmacology and clinical studies of micafungin. Journal of Drug Design, Development and Therapy, 3: 295302, 2009.

3.CLSI - Clinical and Laboratory Standards Institute. Reference method for broth dilution antifungal susceptibility testing yeasts. Approved standard M27-A3, 3rd ed., CLSI, Wayne, 25 pp, 2008..

4. COLOMBO, A. L. Avaliação in vitro por três métodos diferentes da sensibilidade de leveduras a antifungicos azólicos. 1994. 72p. (Tese de Doutorado), Escola Paulista de Medicina, São Paulo. 1994.

5. CURY, A . E. ; MICHE, M.P \& MINAMI, P.S. Leveduras isoladas de pacientes com câncer: incidência e sensibilidade a antibióticos poliênicos. Revista de Microbiologia, 20: 102107, 1989.

6. DUPONT, B.; DENNING, D.W.; MARRIOT, D.;SUGAR, A ;VIVIAN M.A. ; SIRISANTHANA,T. Mycosis in AIDS patients. Journal of Medical and Veterinary Mycology, 32: 65-77, 1994.

7. ESPINEL-INGROFF, A. ; KISH Jr.; C.W. ; KERKERING, T.M.; FROMTLING, R. A .; BARTIZAL, K.; GALGIANI, J.N.;VILLAREAL,K.; PFALLER, M.A. GERARDEN, T.; RINALDI, M.G. ; FOTHERGIL, A .Collaborative comparison of broth macrodilution antifungal susceptibility tests. Journal of Clinical Microbiology, 30: 3138- 45, 1992.
8. GALGIANI, J.N.;RINALDI, M.G.;POLAK,A M. \& PFALLER, M.A. Standartization of antifungal susceptibility testing. Journal of Medical and Veterinary Mycology, 30 (Suppl.1): 213-24,1992.

9.HSUEH, P.R.; LAU, Y.J.; CHUANG, Y.C.; WAN, J.H.; HUANG, W.K.; SHYR, J.M.; YAN, J.J.; YU, K.W.; WU, J.J.; KO, W.C.; YANG, Y.C.; LIU, Y.C.; TENG, L.J.; LIU, C.Y.; LUH, K.T. Antifungal susceptibility of clinical isolates of Candida species,

Cryptococcus neoformans and Aspergillus species from Taiwan: surveillance of multicenter antimicrobial resistance in Taiwan program data from 2003. Antimicrobial Agents and Chemotherapy, 49: 512-517, 2005.

10. IWATA,K. Drug resistence in human pathogenic fungi. European Journal of Epidemiology, 8: 407-21, 1992.

11. JOHNSON, L.B., KAUFFMAN, C.A. Voriconazole: a new triazole antifungal agent. Clinical and Infectious Disease, 36: 630-637, 2003.

12. KERRIDGE, D. \& NICHOLAS, R. O. Drug resistence in the opportunist pathogens Candida albicans and Candida glabrata. Journal of Antimicrobial Chemotherapy, 18 ( Suppl.B): s 39-49, 1986.

13. KORTING, H.C.; OLLERT, M.; GEORGII, A., FROSCHL, M. "In vitro" susceptibilities and biotypesof Candida albicans isolates from oral cavities of patients infected with human immunodeficiency virus. Journal of Clinical Microbiology, 26: 2626-31, 1988.

14. LACAZ, C.S.; PORTO, E.; MARTINS, J. E. C. Micologia Médica. São Paulo: $8^{\mathrm{a}}$ ed. Sarvier, $1991.695 \mathrm{p}$.

15. MACPHAIL, L. M.; GREENSPAN, D.; DODD, C. L.; HEINIC, G. S.; BECK, C, EKOKU E. Association of fungal species with 
oral candidiasis in HIV infection. Journal of

Dental Research, 72:353, 1993

16. MAFFEI, C.M.L. Amostras de C. albicans isoladadas de gestantes: fatores de virulência, sensibilidade a antifúngicos, tipagem fenotípica e genotípica. 1996. (Tese de Doutorado), Instituto de Ciências Biomédicas, Universidade de São Paulo, São Paulo. 1996. 17. MARIO, D. A.N.; DENARDI, L. B.; BANDEIRA, L. A.; ANTUNES, M. S.; SANTURIO, J. M.; SEVERO, L. C.; ALVES, S. H. The activity of echinocandins, amphotericin B and voriconazole against fluconazole-susceptible and fluconazoleresistant Brazilian Candida glabrata isolates. Memórias do Instituto Oswaldo Cruz, 107, 2012.

18. MCGINNIS, M R.; RINALDI, M G. Antifungal drugs: mechanisms of action, drug resistance, susceptibility testing and assays of activity in biological fluids. In: LORIAN V., ed. Antibiotics in laboratory medicine. Baltimore: The Williams \& Wilkins Co., 1996. p 176-211.

19. MEDOFF, G.; KOBAYASHI, G.A. The polyenes. In: SPELLER, D. ed. Antifungal Chemotherapy. New York: John Willey, 1980. p. 3-33.

20. MENON, T.; UMAMAHESWARI, K.; KUMARASAMY, N.; SOLOMON, S.; THYAGARAJAN, S. P. Efficacy of fluconazole and itraconazole in the treatment of oral candidiasis in HIV patients. Acta Tropica, 80: 151-154, 2001.

21. MERZ, W.G.Susceptibility testing of medically important fungi. Advances in Experimental Medicine and Biology, 202: 127-34, 1986.

22. MEYER, R.D. Treatment of fungal infections in patients with HIV-infection or AIDS. Zbl.Bakt, 281: 1-7, 1994.

23. MOHANTY, S.; XESS, I.; HASAN, F.; KAPIL, A.; MITTAL, S.; TOLOSA, J.E.
Prevalence \& susceptibility to fluconazole of Candida species causing vulvovaginitis. Indian Journal of Medical Research, 26: 216-19, 2007.

24. PFALLER, M.A.; BURMEISTER, L.; BARTLETT, M.S; RINALDI, M.G.

Multicenter evaluation of four methods of yeast inoculum preparation. Journal of Clinical Microbiology, 26: 1437-41, 1988.

25. PFALLER, M.A.; DUPONT,B.; KOBAYASHI, G.S.; MUELLER, J.;RINALDI, M.G. ESPINEL-INGROFF, A.; SHADOMY, S.; TROKE, P.F.; WASLH, T.J.;

WARNOCK.D.W. Standardized susceptibility testig of fluconazole; an international collaborative study. Antimicrobial Agents and Chemotherapy, 36: 1805-9, 1992.

26. REX, J.H.; PFALLER, M.A.; POLAK, A; GALGIANI, J.N. Antifungal susceptibility testing. Clinical Microbiology Reviews, 6: 36781, 1993.

27. SAMARANAYAKE L P, MACFARLANE $\mathrm{T}$ W. Oral candidosis. London, United Kingdom: Wright, 1990.

28. SHADOMY, S.; PFALLER, M.A. Laboratory studies with antifungal agents: susceptibility tests quantitation in body fluids and bioassays. In: BALLOWS, A.; HAUSLER JR, W.J.; HERRMANN, K.L.; ISENBERG, H.D.; SHADOMY, H.J. Ed. Manual of Clinical Microbiology, $5^{\mathrm{a}}$ ed. Washington, Americam Society for Microbiology, 1991, p.1173-83.

29. SOUZA, E.M.B.; PAULA, C. R.; PURCHIO, A.; GAMBALE, W.; CORRÊA, B.; CURY, A. E. Aspectos morfo fisiológicos, fatores de virulência e sensibilidade à antifúngicos de amostras de C. albicans, sorotipos A e B, isoladas em São Paulo, Brasil. Revista de Microbiologia, 247-53,1990.

30. TERREL, C.L. \& HUGHES, C.E. Antifungal agents used for deep- seated 
mycotic infections. Mayo Clinic Proceedings, 67:69-91, 1992.

31. WALSH, T,J.;PAUW,B.;ANAISSIE, E. ;MARTINO,P. Recent advances in epidemiology, prevention and treatment of invasive fungal infections in neutropenic patients. Journal of Medical and Veterinary Mycology, 32: 33-51, 1994.

32. YUTHIK, A., SAMARANAYAKE, H.;

LAKSHMAN, P. Experimental Oral

Candidiasis in Animal Models. Clinical

Microbiology Reviews, 14: 398-429, 2001. 